\title{
THE ATTITUDE OF PROFESSIONAL STUDENTS TOWARDS MODERNISATION IN CONTEXT TO SELECTED VARIABLES
}

\author{
Nishi Tyagi ${ }^{1}$
}

Assistant Professor, School of Education, Sharda University, Greater Noida, Gautam Budha Nagar, U.P, India

\author{
Akanksha Srivastava ${ }^{2}$ \\ Associate Professor, School of Education, Sharda University, Greater Noida, Gautam Budha Nagar, U.P, India
}

Anjali Pandey ${ }^{3}$

Assistant Professor, Blue Mountains College of Teacher Education, Dehradun, U.K, India

\begin{abstract}
Modernization is a socio-cultural transition process. This is a systemic transformation mechanism involving principles, norms, systems, and frameworks. The mentality, concept, views, and behaviour of man are therefore oriented to move in that direction. The term modernization is employed not only to identify shifts in a nation's material culture, but also its belief system, beliefs, and way of life in general. It is widely held that education levels decide attitudes to reform and modernization. This research paper is an attempt to study the attitude of the professional students towards modernisation. The sample consists of 185 students studying in various professional colleges located in Greater Noida, GB Nagar, UP. India. It was observed that gender and locality have no impact while choice of stream affects the attitude of professional students towards modernization.
\end{abstract}

Key words- Modernisation, Professional, Students, Attitude

\section{Introduction}

Modernization means a revolutionary change leading to transformation of a traditional or pre moral society into an advanced economically prosperous and relatively politically stable society. The term 'Modernization' doesn't denote any philosophy or movement, but only symbolizes a process of change. In fact, modernization is known as a process which indicates the adoption of recent ways of life and values. According to Haviland (2002) modernization is defined as an all-encompassing universal process of cultural and socio-economic changes, whereby the developing societies seek to accumulate several characteristics common to industrial societies. In due course of modernization, the ancient processes subside to the appliance of scientific knowledge borrowed mainly from the west. Modernization creates the change in traditions and values. People tend to accept this, as progress is not only necessary but also beneficial to society and therefore the individual (Arnold \& Hurn 1966). Modernization includes the emergence and acceptance of a different behavioural system with certain unique characteristics. It refers to the in-depth changes in way of thinking and feeling i.e. a complete change in attitude to life's problems, the society and therefore the universe.

The changes witnessed by our society in the last centuries and the trend of 'modernization' has affected our lives profoundly. According to Lerner (1964), modernization is the social process of which development is the economic component. Modernization does not mean that ancient value has been rooted out. In her operational interpretation of the concept of modernization, Sushila Jain (1986) points out that the word denotes transition not only in the sacred and unholy current components of social organization but also in the new form of rational social, economic, cultural and political values, means and relationships, Education is the most significant instrument for modernisation, as it incorporates: Enhancement in the system of practices, beliefs, and values. In the institutional network, it increases the acceptability of digital technology, its organizational and operational sense and growth of infrastructure needed to meet the national needs of foreign-sourced technologies; Laying the foundations of institutions and organisations that could take responsibility for independent innovation and timely technological advancement for the 
country's needs and problems. Attitude is an extent of being positively or negatively linked to a certain psychological object. In the present study, however, the attitude towards modernity refers to the mental composition of the individual towards modernization with four dimensions, such as socio-religious, marriage, women's position, and education.

\section{Rational of the Study}

Education and Modernization are closely related to each other. Education serves as an effective instruction for effective modernization. To modernize itself a society must educate itself, the spread of education in rapid strides is essential. The cream of intelligence is but the product of educational churning.

The importance of this study lies in the fact that modernization plays an important role in the enlargement of social awareness. Modernization leads to a desired type of changes in the social, cultural, and religious values. It changes the perception of the people to deal with their environment. Modernization affects the student's behaviour and attitude towards the society, so modernization is important for the students.

Rath (1973) writes "whatever may be the sociocultural factors of social change, on the psychological plane, it involves a great conflict between the old and new, the traditions and modernity, the aged and youth." Modernity is a very comprehensive viewpoint which puts emphasis upon the new, the present, the real, and the scientific, as well as upon liberty, equality, fraternity, and justice. Despite this great importance of modernization, only a few studies have been conducted at state and regional level on students. Realizing the importance of modernization in society and the role which the young generation is supposed to play in strengthening social order, the investigator felt interested in undertaking a study on attitude towards modernization of students, enrolled in professional courses with respect to the gender, stream and locality.

\section{Statement of the Problem}

The problem selected for the purpose of the present study reads as: The attitude of professional students towards modernisation in context to selected variables.

\section{Review of the Literature}

Previous researches have shown that seminal contribution has been made in the area of attitude towards modernisation. But a closer look at literature review in this area reveals a number of gaps in the knowledge related to attitude towards modernisation. To fill this literature, gap the present study is an effort to address the attitude of specifically professional students towards modernisation. To our knowledge no prior studies have examined this problem. This section presents a review of recent literature related to the problem under consideration.

Ekka, Nancy(2013) studied the impact of modernization on tribal religious customs and traditions of Rourkela and concluded that due to the trend of modernization in these tribal villages, the tribal perceptions, thoughts, food habits, daily life styles, dresses, festivals, rule and rituals, the eco-friendly, nature related culture etc., are all deteriorating. As modernization has entered tribal lifestyle, there is a chance to lose the traditions and tribal uniqueness in the long run, in the changing scenario. Pooja Malik, Swati Gupta II \& Anita Jan (2013) studied Attitude towards modernization of under-graduate students. The study revealed that choice of subjects has no impact while gender affects the attitude of undergraduate students towards modernization.

Ganaie,M.Y \& Hafiz Mudasir (2013) worked upon the Modernization of Higher Secondary School Students with respect to Science and Social Science background The results showed that the science higher secondary school students differ significantly from their social science counterpArtss on modernization level, the science students being higher on the level of modernization.

Alka Panwar \& Uma Chaudhary (2015) worked upon 'Impact of Sex on the Attitude towards Modernization among Hindu youths' and found that in this research paper I conclude that attitude towards modernization affected by sex. (Artsicle, Impact of Sex on the Attitude towards Modernization among Hindu youths. Bilal Ahmad Naikoo and Shabir Ahmad Bhat (2016), performed a study on Modernization in relation to value orientation of college going students: A study of Kashmir valley. The study revealed a significant difference between male and female 
college students on modernization on the other hand male students show significantly higher results on three dimensions of value orientation. Results also reveal that there is no significant difference in the other two dimensions of value orientation (Autocratism-Democratism and NonEmpathy-Empathy value orientation) of male and female college students. Further results revealssignificant positive relationship between modernization and value orientation of college students.

Shobha \& Seema Dhawan, (2017) researched the Attitude of Tribal and Nontribal students towards Modernization Tribal student's attitude towards modernization has been found comparatively low. On the other hand, tribal students, specifically male students, have shown a higher positive attitude towards modernization.

Samee Gupta (2017) studied the attitude of graduate level students towards modernization and found that there is a difference in attitude of male and female graduates, Science and Artss graduates, rural and urban area graduates, and graduates of single and combined families. There is no significant difference in the attitude of male and female graduate students of single family as well as combined family.

Pinki Ninaniya, Santosh Sangwan, Reena \& Shanti Balda (2017) examined the Attitude of Adolescents Towards Modernization: A Comparative Study. The results of the study pinpointed that urban respondents had more positive attitudes on education, parent child relationship, politics, and the status of women aspects of modernization as compared to their counterparts.

Reyaz Ahmad Shameem (2017) attempted to investigate and compare the attitude of rural and urban college girls towards modernization in district Srinagar. Rural/urban factors have a significant impact on the attitude of college girls towards modernization. Ranjit Kaur Bhalla (2018) found that there is a significant relationship between attitude towards Modernization and Emotional Competence.

There is a dearth of researches to explore the attitudes of students enrolled in professional courses towards modernization. The overall attitudes towards modernization and the variation in the attitudes of respondents with reference to gender, locality and stream has received almost negligible attention in the context of Greater Noida. The current research attempts to eliminate this gap in research. Furthermore, this research contributes to an understanding of the attitude towards modernization of students who are enrolled in professional courses. It also offers valuable scope to fill the gap concerning attitudinal studies on several variables including age, language, culture, and socio-economic status of university students.

\section{Objectives of the Study}

1. To study the attitude of Professional students towards modernization in terms of following dimensions: - (a) Socio-religion (b) Position of women (c) Marriage (d) Education.

2. To study the attitude of male and Female professional students towards modernization in terms of different dimensions.

3. To equate the attitude of rural and urban professional students towards modernization in terms of different dimensions.

4. To compare the attitude of Arts and science professional students towards modernization in terms of different dimensions.

\section{Hypotheses of the Study}

\section{There is no significant difference between the total mean scores of the attitude of male and female professional students towards modernization.}

1.1.There is no significant difference between the mean scores of the attitude of male and female professional students towards modernization in terms of different dimensions of Modernization. (1) Socio- Religious (2) Marriage (3) Position of Women (4) Education

2. There is no significant difference between the mean scores of the attitude of rural and urban professional students towards modernization.

2.1.There is no significant difference between the mean scores of the attitude of rural and urban students enrolled in professional courses towards modernization in terms of different dimensions of modernization. Socio- Religious (2) Marriage (3) Position of Women (4) Education 
3. There is no significant difference between the mean scores of the attitude of Arts and science stream professional students towards Modernization.

3.1. There is no significant difference between the mean scores of the attitude of Arts and science stream professional students towards modernization in terms of different dimensions of modernization.

(1) Socio- Religious (2) Marriage (3) Position of Women (4) Education

Method of the study

The purpose of the study is to investigate the attitude of students enrolled in professional courses towards modernization. For this purpose, a survey method is used.

Sample: The sample for the present study consisted of 185 students studying in various professional colleges (Arts and Science stream) of Greater Noida, GB Nagar, UP. A total number of 185 students were selected through Purposive sampling technique. The sample consisted of 86 boys and 99 girls from urban and rural backgrounds.

Tool used: In this study, the investigator selected the Attitude scale of Modernization prepared by Raghavendra S. Singh, Amar Nath Tripathi, Ramjee Lal for collecting the data about attitudes on the modernization of students. The scale consists of 32 items in four dimensions which are socio-religious, marriage, the position of women, and education. Two types of scores were obtained, area wise modernization score, and a total score indicating overall modernization. Each dimension contains both types of items- positive and negative. The responses of each statement are on a six-point scale namely-extremely agree, strongly agree, disagree, strongly disagree, and extremely disagree.

Conceptual Model: The conceptual model as shown in Figure 1. represents the impact of Gender, Locality and Stream on Modernisation with its dimensions.

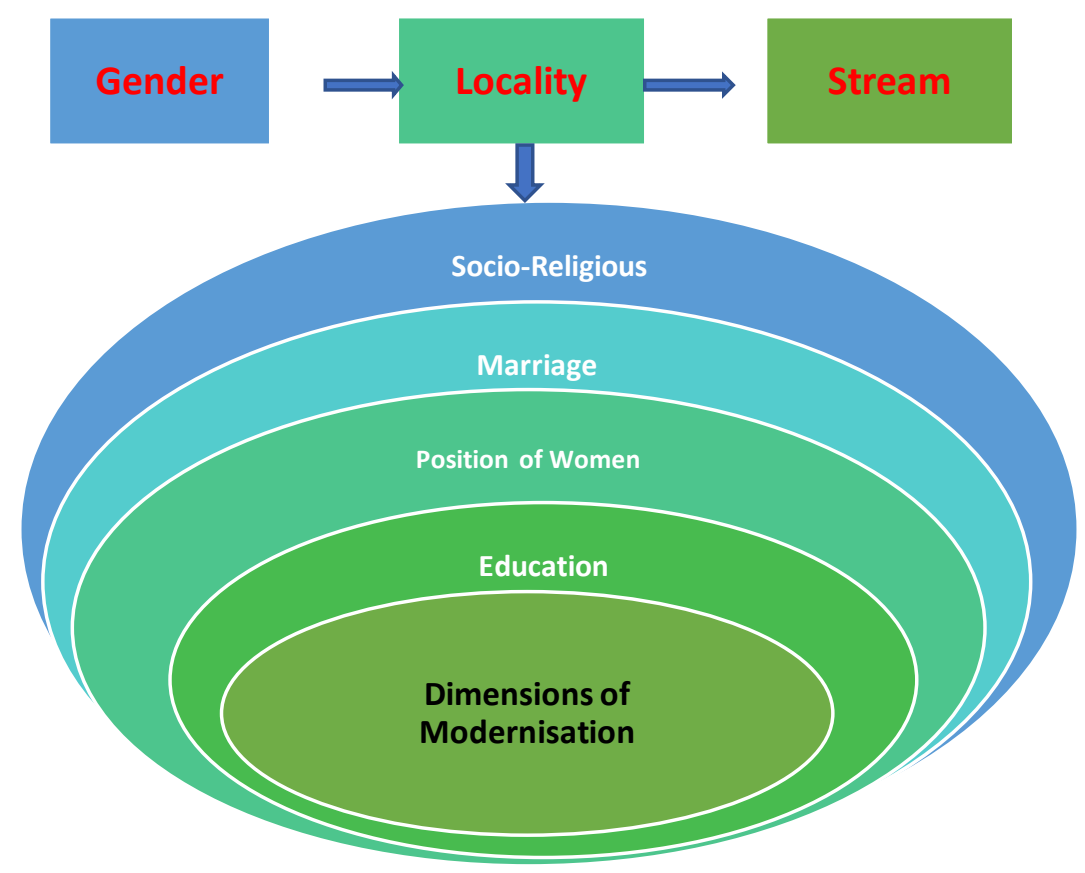

Figure.1. Proposed framework showing the impact of Gender, Locality and Stream on Modernisation with its dimensions.

\section{Analysis and interpretation of data}

The statistical treatment of the data and the results obtained there upon has been arranged in a tabular form and is presented below:
Table 1. Comparison between the total mean scores of the attitude of male and female professional students towards modernization. 


\begin{tabular}{|l|c|c|c|c|c|}
\hline Gender & No. & Mean & SD & 't' value & Remark \\
\cline { 1 - 4 } Male students & 86 & 134.29 & 14.78 & \multirow{2}{*}{1.96} & NS \\
\cline { 1 - 4 } Female students & 99 & 129.76 & 16.63 & & \\
\hline
\end{tabular}

Interpretation: Table. 1 reveals that the mean score of male students is 134.29 with S.D. 14.78. The mean score of female students is 129.76 with S.D 16.63 and t- value is 1.96 which is significant at 0.05 level. Hence, the hypothesis "There is no significant difference between the total mean scores of the attitude of male and female professional students towards modernization" has been accepted. So, it can be concluded that there is no significant difference in the attitudes towards modernization of male students and female students. Although, the mean scores of male students are higher than the female students which indicates that male students have more favourable attitude towards modernization than the Female students. But ' $t$ ' value (1.96) shows that gender contributes a little as far as the attitude of male students towards modernization is concerned and the negligible difference between mean is just by chance.

\section{Comparison between Male and Female Students}

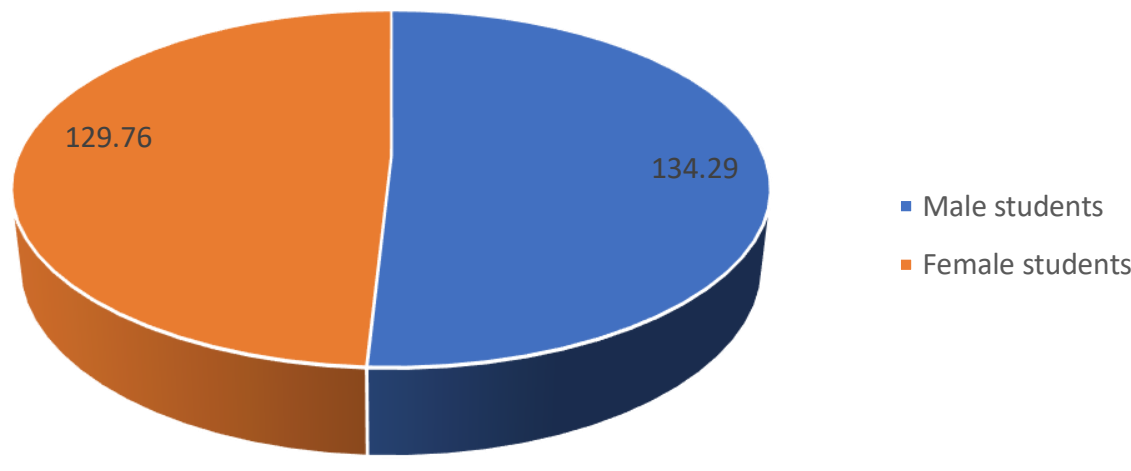

Figure 2: Distribution of mean scores of male and female professional students on attitude towards modernization.

Table 1.1. Comparison between the mean scores of the attitude of male and female

\begin{tabular}{|c|c|c|c|c|c|c|}
\hline $\begin{array}{c}\text { Dimensions } \\
\text { of } \\
\text { Modernisation }\end{array}$ & Groups & No. & $\begin{array}{l}\text { Mea } \\
\mathbf{n}\end{array}$ & $\begin{array}{c}\text { S } \\
\text { D }\end{array}$ & $\begin{array}{c}\text { t- } \\
\text { value }\end{array}$ & $\begin{array}{c}\text { Rema } \\
\text { rks }\end{array}$ \\
\hline $\begin{array}{c}\text { Socio } \\
\text { religious }\end{array}$ & $\begin{array}{c}\text { Male } \\
\text { students }\end{array}$ & 86 & 134. & 14 & 1.96 & NS \\
\hline
\end{tabular}

professional students towards modernization in terms of different dimensions. 


\begin{tabular}{|c|c|c|c|c|c|c|}
\hline & $\begin{array}{l}\text { Female } \\
\text { students }\end{array}$ & 99 & $\begin{array}{l}129 . \\
76\end{array}$ & $\begin{array}{c}16 \\
.63\end{array}$ & & \\
\hline \multirow[t]{2}{*}{ Marriage } & $\begin{array}{r}\text { Male } \\
\text { students }\end{array}$ & 86 & $\begin{array}{l}29.7 \\
0\end{array}$ & $\begin{array}{c}5 . \\
79\end{array}$ & \multirow[t]{2}{*}{1.35} & \multirow[t]{2}{*}{ NS } \\
\hline & $\begin{array}{l}\text { Female } \\
\text { students }\end{array}$ & 99 & $\begin{array}{l}28.5 \\
2\end{array}$ & $\begin{array}{c}6 . \\
20\end{array}$ & & \\
\hline \multirow[t]{2}{*}{$\begin{array}{l}\text { Position of } \\
\text { women }\end{array}$} & $\begin{array}{r}\text { Male } \\
\text { students }\end{array}$ & 86 & $\begin{array}{l}38.8 \\
9 \\
\end{array}$ & $\begin{array}{r}5 . \\
97 \\
\end{array}$ & \multirow[t]{2}{*}{0.24} & \multirow[t]{2}{*}{ NS } \\
\hline & $\begin{array}{l}\text { Female } \\
\text { students }\end{array}$ & 99 & $\begin{array}{l}38.6 \\
7\end{array}$ & $\begin{array}{c}6 . \\
27\end{array}$ & & \\
\hline \multirow[t]{2}{*}{ Education } & $\begin{array}{r}\text { Male } \\
\text { students }\end{array}$ & 86 & $\begin{array}{l}34.4 \\
4\end{array}$ & $\begin{array}{r}6 . \\
41 \\
\end{array}$ & \multirow[t]{2}{*}{0.79} & \multirow[t]{2}{*}{ NS } \\
\hline & $\begin{array}{l}\text { Female } \\
\text { students }\end{array}$ & 99 & $4^{33.7}$ & $63^{5 .}$ & & \\
\hline
\end{tabular}

Interpretation: A perusal at table 1.1 shows that the mean score of the attitude of male students is 134.29 with S.D. 14.78. The mean score of the attitude of female students is 129.76 with S.D 16.63. The $t-$ value is 1.96 which is not significant at 0.05 level. So, it can be concluded that there is no significant difference between the attitude of male and female students enrolled in professional courses towards socio religious.

The data shows that that the mean score of the attitude of male and female students towards marriage are 29.70 with S.D. 5.79 and 28.52 with S.D. 6.20 respectively. The ' $t$ ' value is 1.35 which is not significant at 0.05 level. but ' $t$ ' value shows that gender has no impact on attitude towards marriage of professional students. it can be concluded that Male and female students having similar attitude towards marriage.

It is clear from table II that the mean scores of the attitude male \& female professional students towards position of women are 38.89 with S.D.
$5.97 \& 38.67$ with S.D 6.27 respectively. The calculated ' $t$ ' value is 0.24 , which is not significant at the 0.05 level. It shows that gender has not significant impact on the attitude of professional students towards position of women.

The data shows that the mean scores of male \& female professional students towards Education are 34.44 with S.D. $6.41 \& 33.74$ with S.D 5.63 respectively. The calculated ' $t$ ' value is 0.79 which is not significant at the 0.05 level. It shows that gender does not has a significant impact on the attitude of professional students towards Education.

Thus, the null hypothesis "There is no significant difference between the mean scores of the attitude of male and female professional students towards modernization in terms of different dimensions." has been accepted. It can be concluded that slightly difference in the mean of male and female students on attitude towards position of women is just by chance and gender has no impact on attitude towards modernization. 


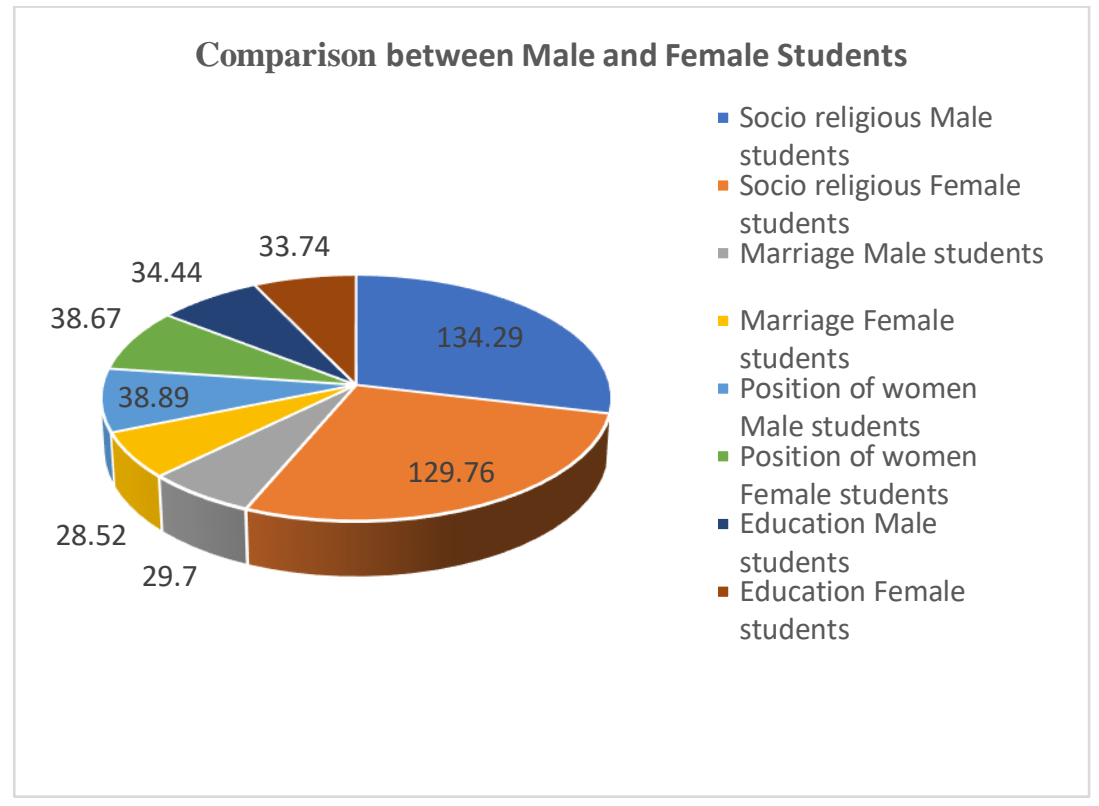

Figure 3: Distribution of mean scores of male and female professional students on attitude towards dimensions of modernization.

Table 2.0: Comparison between the total mean scores of the attitude of Rural and Urban professional students towards modernization

\begin{tabular}{|l|c|c|c|c|c|}
\hline Gender & No. & Mean & SD & 't' value & Remarks \\
\cline { 1 - 4 } Rural students & 90 & 131.24 & 15.98 & 0.67 & NS \\
\cline { 1 - 3 } Urban students & 95 & 132.86 & 16.29 & & \\
\hline
\end{tabular}

Interpretation: Table 2 shows that the ' $\mathrm{t}$ ' value is 0.67 which is less than the ' $t$ ' value at 0.05 level of significance. Hence the null hypothesis "There is no significant difference between the total mean scores of the attitude of rural and urban professional students towards modernization" has been accepted. It can be said that rural and urban students do not differ significantly in their attitude towards modernization.

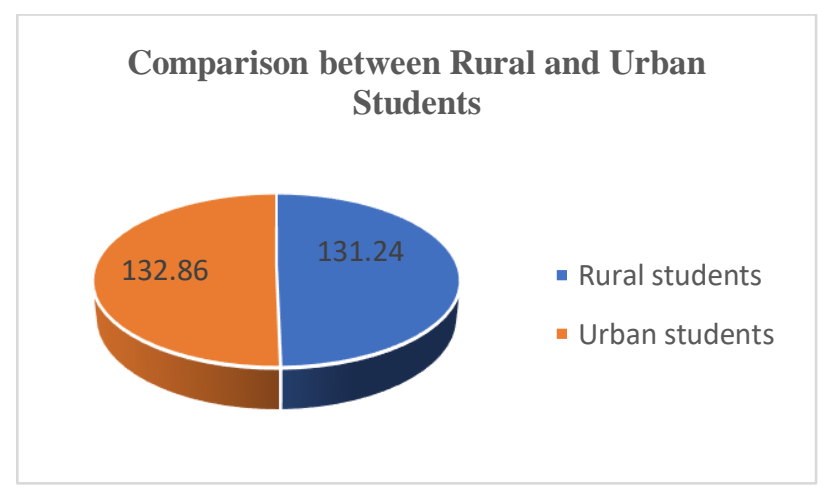

Figure 4: Distribution of mean scores of rural Urban and professional students on attitude towards modernization

Table 2.1: Comparison between the mean scores of the attitude of Rural and Urban professional students towards modernization in terms of different dimensions. 


\begin{tabular}{|c|c|c|c|c|c|c|}
\hline $\begin{array}{c}\text { Dimensions of } \\
\text { Modernisation }\end{array}$ & $\begin{array}{c}\text { Group } \\
\text { S }\end{array}$ & $\begin{array}{l}\text { No } \\
\text {. }\end{array}$ & Mean & SD & $\begin{array}{r}\text { t- } \\
\text { value }\end{array}$ & $\begin{array}{c}\text { Rem } \\
\text { arks }\end{array}$ \\
\hline \multirow[t]{2}{*}{ Socio- religious } & $\begin{array}{r}\text { Rural } \\
\text { students }\end{array}$ & 90 & 28.22 & 5.82 & \multirow[t]{2}{*}{$\begin{array}{l}1.8 \\
4\end{array}$} & \multirow[t]{2}{*}{ NS } \\
\hline & $\begin{array}{r}\text { Urban } \\
\text { students }\end{array}$ & 95 & 29.84 & 6.15 & & \\
\hline \multirow[t]{2}{*}{ Marriage } & $\begin{array}{r}\text { Rural } \\
\text { students }\end{array}$ & 90 & 31.20 & 5.82 & \multirow[t]{2}{*}{.81} & \multirow[t]{2}{*}{$\mathrm{NS}$} \\
\hline & $\begin{array}{l}\text { Urban } \\
\text { students }\end{array}$ & 95 & 31.91 & 6.01 & & \\
\hline \multirow[t]{2}{*}{$\begin{array}{l}\text { Position of } \\
\text { women }\end{array}$} & $\begin{array}{r}\text { Rural } \\
\text { students }\end{array}$ & 90 & 38.64 & 6.68 & \multirow[t]{2}{*}{.75} & \multirow[t]{2}{*}{ NS } \\
\hline & $\begin{array}{r}\text { Urban } \\
\text { students }\end{array}$ & 95 & 39.34 & 5.96 & & \\
\hline \multirow[t]{2}{*}{ Education } & $\begin{array}{r}\text { Rural } \\
\text { students }\end{array}$ & 90 & 34.10 & 6.66 & \multirow[t]{2}{*}{0.1} & \multirow[t]{2}{*}{ NS } \\
\hline & $\begin{array}{l}\text { Urban } \\
\text { students }\end{array}$ & 95 & 34.01 & 5.95 & & \\
\hline
\end{tabular}

Interpretation: The table 2.1 depicts that the mean scores of rural Students is 28.22 with SD 5.82 and the mean score of urban students is 29.84 with SD 6.15 respectively. The calculated ' $t$ ' value is 1.84 which is not significant at the 0.05 level of significance. It shows that locality does not has a significant impact on the attitude of students towards socio religious and the difference between the attitude of rural and urban students towards socio religious is by chance. It can be said that there is no significant difference in mean scores of the attitude of rural and urban professional students towards modernization towards socio- religious reforms.

The mean scores of professional students, belonging to rural area is 31.20 with S.D. 5.82 and the mean scores of professional students, belonging to urban area is 31.91 with S.D 6.01. The $\mathrm{t}$ - value comes out to be .75 which is not significant at 0.05 level. Hence, it can be inferred that there is no significant difference of the attitude of rural and urban professional students towards marriage.

The data shows that, the mean scores of professional students, belonging to rural area is 38.64with S.D. 6.68 and the mean scores of professional students, belonging to urban area is 39.34 with S.D. 5.96. The t- value comes out to be .84 which is not significant at 0.05 level. Hence, it can be inferred that there is no significant difference of the attitude of the rural and urban professional students towards Position of women.

The table shows that the mean scores of professional students, belonging to rural area is 34.10 with S.D. 6.66 and the mean scores of professional students, belonging to urban area is 34.01 with S.D. 5.95. The t- value comes out to be .84 which is not significant at 0.05 level. Hence, it can be inferred that there is no significant difference in the attitude towards Education of rural and urban professional students.

Thus, the null hypothesis, "There is no significant difference between the mean scores of the attitude of Rural and Urban professional students towards modernization in terms of different dimensions." has been accepted. 


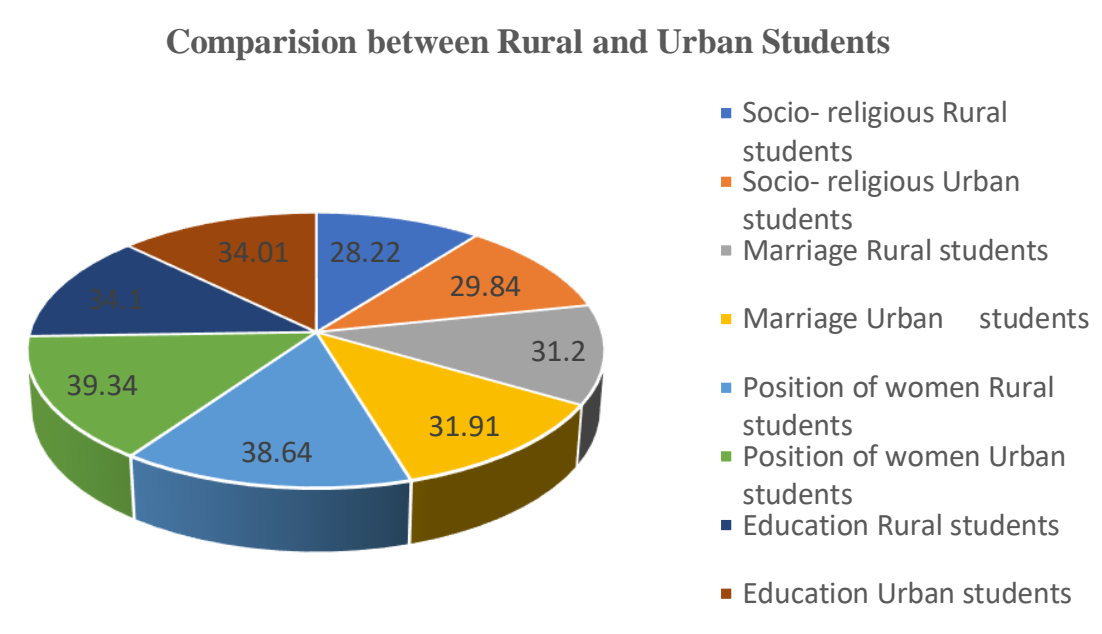

Figure 5: Distribution of mean scores of rural and urban professional students on attitude towards dimensions of modernization.

Table 3.0: Comparison between the mean scores of the attitude of Arts and Science stream professional students towards modernization in terms of different dimensions.

\begin{tabular}{|c|c|c|c|c|c|}
\hline Group & No. & Mean & SD & 't' value & Remark \\
\hline $\begin{array}{l}\text { Students of Arts } \\
\text { Stream }\end{array}$ & 90 & $4^{125.8}$ & $4^{14.7}$ & 5.37 & Significant \\
\hline $\begin{array}{r}\text { Students of } \\
\text { Science Stream }\end{array}$ & 95 & $6^{137.6}$ & $2^{15.1}$ & & \\
\hline
\end{tabular}

Interpretation: The data shows that the ' $\mathrm{t}$ ' value is 5.37 which is greater than the ' $t$ ' value at 0.05 level of significance. Hence the null hypothesis - "There is no significant difference in mean scores of the attitude of Arts and Science stream students towards modernization" has been rejected so, it can be said that professional students of science and Arts stream differ significantly in their attitude towards modernization.

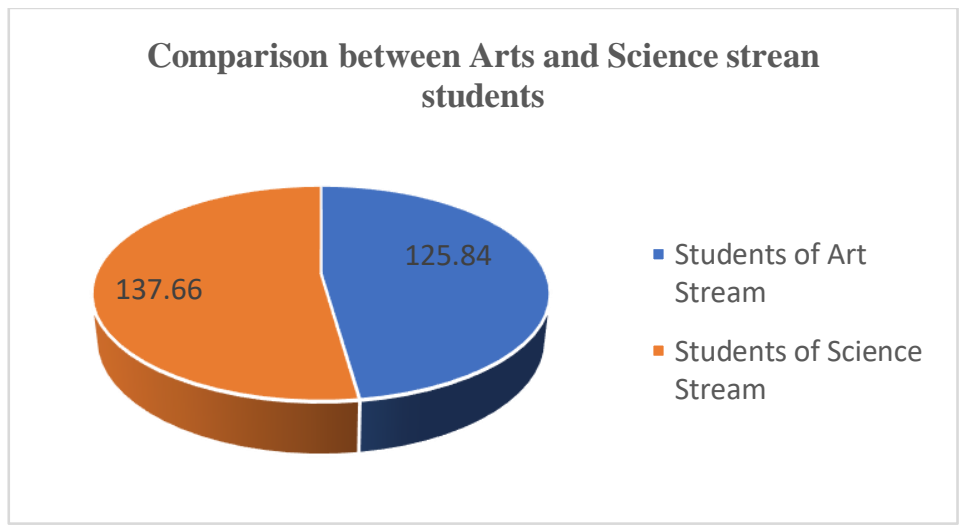

Figure 6: Distribution of mean scores of arts and science professional students on attitude towards modernization 
Table. 3.1: Comparison between the mean scores of the attitude of Arts and Science stream professional students towards modernization in terms of different dimensions.

\begin{tabular}{|c|c|c|c|c|c|c|}
\hline $\begin{array}{c}\text { Dimensions of } \\
\text { Modernisation }\end{array}$ & Groups & No. & Mean & SD & $\begin{array}{r}\text { t- } \\
\text { value }\end{array}$ & Remark \\
\hline \multirow[t]{2}{*}{$\begin{array}{l}\text { Socio- } \\
\text { religious }\end{array}$} & $\begin{array}{l}\text { Students of } \\
\text { Arts stream }\end{array}$ & 90 & 27.73 & 6.18 & \multirow[t]{2}{*}{2.93} & \multirow[t]{2}{*}{ Significant } \\
\hline & $\begin{array}{l}\text { Students of } \\
\text { Science } \\
\text { stream }\end{array}$ & 95 & 30.31 & 5.75 & & \\
\hline \multirow[t]{2}{*}{ Marriage } & $\begin{array}{l}\text { Students of } \\
\text { Arts stream }\end{array}$ & 90 & 30.45 & 5.84 & \multirow[t]{2}{*}{2.42} & \multirow[t]{2}{*}{ Significant } \\
\hline & $\begin{array}{l}\text { Students of } \\
\text { Science } \\
\text { stream }\end{array}$ & 95 & 32.45 & 5.49 & & \\
\hline \multirow[t]{2}{*}{$\begin{array}{l}\text { Position of } \\
\text { women }\end{array}$} & $\begin{array}{l}\text { Students of } \\
\text { Arts stream }\end{array}$ & 90 & 37.82 & 5.80 & \multirow[t]{2}{*}{1.98} & \multirow[t]{2}{*}{ Significant } \\
\hline & $\begin{array}{l}\text { Students of } \\
\text { Science } \\
\text { stream }\end{array}$ & 95 & 39.59 & 6.39 & & \\
\hline \multirow[t]{2}{*}{ Education } & $\begin{array}{l}\text { Students of } \\
\text { Arts stream }\end{array}$ & 90 & 32.19 & 5.71 & \multirow[t]{2}{*}{4.46} & \multirow[t]{2}{*}{ Significant } \\
\hline & $\begin{array}{l}\text { Students of } \\
\text { Science } \\
\text { stream }\end{array}$ & 95 & 35.94 & 5.70 & & \\
\hline
\end{tabular}

Interpretation: It is clear from the table that the mean scores of professional students of Arts stream are 27.73 with SD 6.18 and the mean scores of professional students of science stream is 30.31 with SD 5.75. The calculated ' $t$ ' value is 2.93 which is greater than the ' $t$ ' value at 0.05 level of significance. It shows that choice of stream has significant impact on the attitude of professional students towards social religious reform and the difference between the mean scores is not by chance.

The data shows that the mean scores of professional students of Arts stream are 30.45 with SD 5.84 and the mean scores of professional students of science stream is 32.45 with SD 5.49. The calculated ' $t$ ' value is 2.42 which is greater than the ' $t$ ' value at 0.05 level of significance. It shows that choice of stream has significant impact on the attitude of professional students towards marriage. The difference is quite visible to say that the students of science stream have more positive attitude than the Arts students towards marriage.
The data shows that the mean scores of professional students of Arts stream are 37.82 with SD 5.80 and the mean scores of professional students of science stream is 39.49 with SD 6.39. The calculated ' $t$ ' value is 1.98 which is greater than the ' $t$ ' value at 0.05 level of significance. It shows that choice of stream has also significant impact on the attitude of professional students towards position of women.

It is clear from the table that the mean scores of Professional students of Arts stream are 32.19 with SD 5.71 and the mean scores of Professional students of science stream are 35.94 with SD 5.70 respectively. The calculated " $t$ " value is 4.46 which is significant. It shows that stream has a significant impact on the attitude of professional students towards Education and the difference between the attitude of science and Arts professional students is not by chance. Thus, the hypothesis "There is no significant difference between the attitude of Arts and science stream professional students towards modernization in terms of different dimensions" has been rejected. 
It can be concluded that science students scored higher on the attitude towards modernization than their Arts counterparts. Thus, they have more favourable attitude towards modernization than their Arts counterparts Arts.

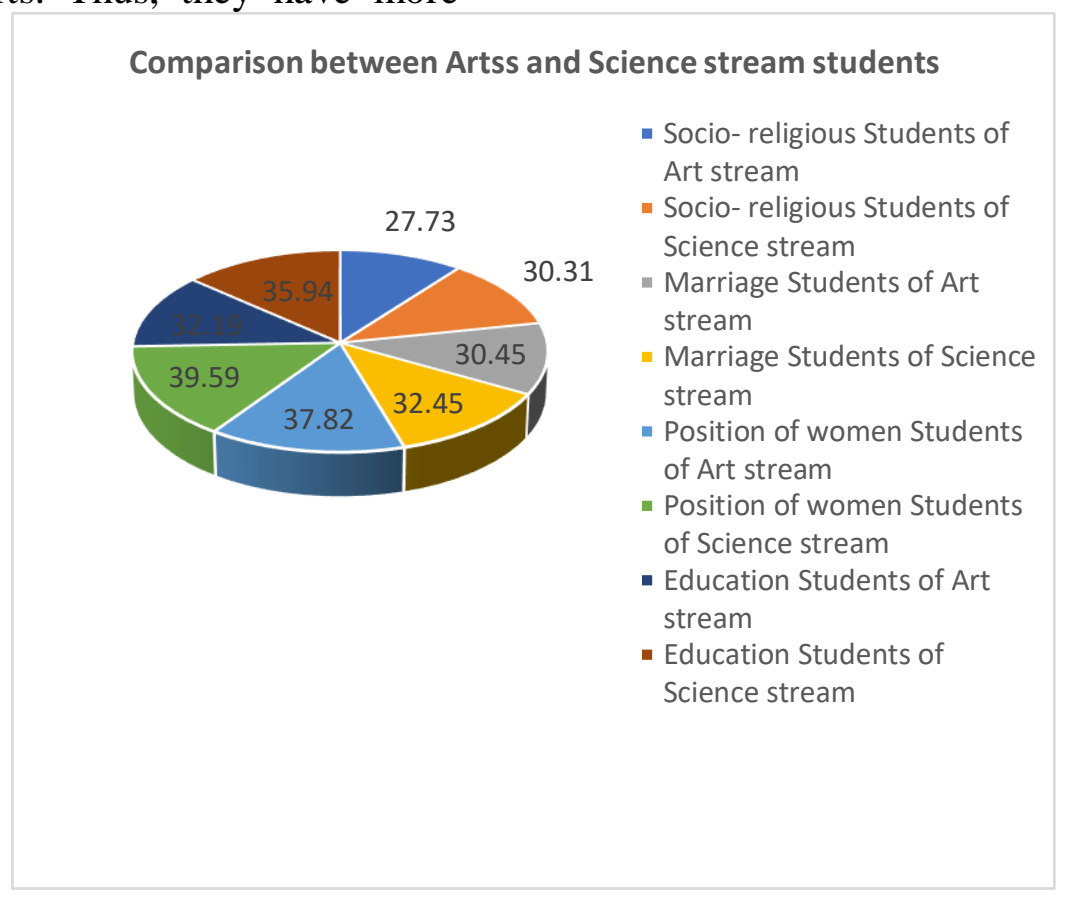

Figure 7: Distribution of mean scores of Arts and Science professional students on attitude towards dimensions of modernization.

\section{Findings of the study}

This study was confined to find the attitude towards modernization of the students enrolled in professional courses. Based on statistical analysis and in the light of empirical evidence, the following conclusions have been drawn:

1. There was no significant difference in the attitude of male and female students towards modernisation, in relation to socio-religious, marriage, position of women, education.

2. It was found that the professional students belonging to rural area do not differ significantly from their urban counterparts Arts on the scores obtained on the dimension of modernisation.

3. It is evident that the professional students of science stream differ significantly from their Arts counterparts Arts on modernization, the science students being higher on the level of modernization.

\section{Conclusion}

For the current work, it is sufficient to point out that gender and locality are not among the major contributors for the difference in attitude towards modernisation. But at the same time, it turns out that Stream of studies has a significant role to play in developing a positive attitude towards modernisation. The evaluation of the data presented in this work leads to conclude that scientific attitude plays an important role in modernizing people in a channelled way, as it can act as the initiator as well as the recipient of social change. The present research has both theoretical and practical implications. The results are significant for educational institutions from a practical point of view. Education is usually considered to mould the character of the society. It allows the individual to participate fully in nation's development. The research has implications for teachers, too. It is the teacher who is delivering the learning material to the students. He has a crucial role in the students ' development of the right kind of outlook and attitudes. The instructor must therefore offer instruction in such a way that the students will establish a self-concept, a logical 
perspective, scientific attitude, questioning mind, and the ability to make their own decisions.

\section{References}

1. Sharma, A.K. (1988-92). Fifth Survey of Educational Research, Trend Reports Vol. I. NCERT.

2. Bhat, S.\& Naikoo, Bilal, (2016). Modernization in relation to value orientation of college going students: A study of Kashmir valley. Indian Journal of Health and Wellbeing 7(4), 446-448. http://www.iahrw.com.

3. Anderson C.A. (1966). Modernization of Education in Modernization; The Dynamics of Growth. Ed, Myron Weiner.

4. Aswathappa, K. (2000). Organizational Behaviour. Mumbai (5th Ed.) Himalaya Publishing House, pp.163,169.

5. Bhalla, R.K. (2018). A study attitude towards modernization in relation to emotional competence of secondary school students. Global journal for research analysis, volume7, issue-1, print ISSN 2277-8160.

6. Bhatia. S.K. (2002). Business Ethics and Managerial Values. New Delhi: Deep and Deep Publication.

7. Buch, M.B. Ed (1991), Fourth Survey of Research in Education, New Delhi, NCERT.

8. Chaudhari, R. (2012). A Study of Attitudes of B.Ed. Trainees Towards Modernization, IIR Journal, Vol.1. (1).

9. Ekka, N. (2013) Impact of Modernisation on Tribal Religious Customs and Traditions: A Case Study of Rourkela. MA thesis.

10. Ganaie, M.Y, \& Mudasir, H. (2013) Modernization of Higher Secondary School Students with Respect to Science and Social Science Background. Researcher, Science Journal;5(12):97-101]. (ISSN: 1553-9865). http://www.sciencepub.net/researche.

11. Gupta, A. (2003). Occupational Stress and Basic Values: A Motivational Approach.
Recent Researches in and Psychology,8 (111), pp. 62

12. Gupta, S. (2017). A study of the attitude of graduate level students towards modernization, International Educational and Research Journal, E-ISSN 2454-9916, Vol 3, Issue 5, pp. 355-357.

13. Hofstede, G. (2001). Cultures Consequences: International Differences in Work Related Values (2nd Ed.). Beverly Hills: Sage Publications, pp.5-6,8.

14. Kapil, H.K. Aggarwal, S. (1967). Changing Pattern of Values Amongst Women in Modern Hindu Society. Journal of Psychological Researches, 2 (1\&2), pp. 29-32.

15. Katiyar, P.C. (1987). Values and Vocational Preferences. Agra: Bhargava Book House. Kuppuswamy, B. (2004), Social Change in India, Delhi: Konark Publication.

16. Menon, A. (2012). Impact of Modernization on values of students. International journal of research in education methodology, 1(2), 1-7. https://doi.org/10.24297/ijrem.v1i2.4126.

17. National Policy on Education. (1986). Ministry of Human and Development. DepArtsment of Education, Govt. of India, New Delhi.

18. Panwar, A. \& Chaudhary, U. (2015). Impact of Sex on the Attitude towards Modernization among Penguin Dictionary of Psychology. (2003). 3rd Ed. London: Penguin Books, pp.783.

19. Ninaniya, P., Sangwan, S. Reena \& Balda, S. (2017). Attitude of adolescents towards modernization a comparative study. International journal of educational science and research (IJESR) ISSN(p): 2249-6947; ISSN(e) 2249-8052 vol. 7, issue 3, pp. 27-34.

20. Malik, P., Gupta, S. \& Jain, A. (2013). Attitude towards Modernization of under-graduate students, International journal of Advancements in Education and Social Sciences, ISSN 2322-0023, Vol. No.1, pp.1319. 
21. Prentice, D.A. (2000). Values in Encyclopaedia of Psychology. Oxford: Oxford University Press, pp. 153-154.

22. Rath, R. (1973). Psycho-social problems of social changes. Bombay, Allied Publishers.

23. Reyaz, A. S. (2017). Attitude towards Modernization-a study of rural and urban college girls in district srinagar, e-ISSN 24549916, volume, 3, issue, 2.

24. Shastree, N.K. (2004). Issues in Value Education: Developing a Synthetic Approach. University News, 42 (46), 164-166.

25. Shobha \& Dhawan, S. (2017). Attitude of Tribal and Non Tribal students towards modernization, Scholarly Research Journal for Humanity Science \& English Language, Online ISSN 2348-3083, VOL- 4/23, online resource,https://doi.org/10.21922/srihsel.v4i2 3.9651.

26. Singh, R.P., Tripathi, A.N., \& Ramjilal, (1979). National psychological corporation,4/230, Kacheri Ghat, Agra.

27. Singh, R. (2005). The modernization Scale, Agra, National Psychological corporation.

28. Singh, V.P. (2004). Value inculcation Among Younger Generation: A Suggested Model. University News, 42 (5), 11-12. 